Institute of $\mathbf{F}_{\text {ood and }} \mathbf{A}_{\text {gricultural }} \mathbf{S}_{\text {ciences }}$

\title{
Nematode Management on Perennial Landscape Plants ${ }^{1}$
}

\author{
William T. Crow ${ }^{2}$
}

One of the appeals of Florida is the variety of vegetation that can be grown here. Ornamental plants beautify our environment and are a vital part of the Florida economy. Often trees and shrubs are the major features that our landscapes are designed around. Many of us grow citrus and other tropical fruits in our landscapes for beauty, and also to get tasty treats. Unfortunately, we are not the only ones who like these plants. Other organisms see our landscape plants as a food source and can cause considerable damage to them. These may be things we can see like rabbits, birds, or insects. Other times they may be invisible, too small to be seen. Due to our warm temperatures, sandy soil, and humidity Florida has more than it's fair share of these pests and pathogens. Plant-parasitic nematodes (Figure 1) can be among the most damaging and hard-to-control of these organisms.

\section{What are Nematodes?}

Nematodes are unsegmented roundworms, different from earthworms and other familiar worms that are segmented (annelids) or in some cases flattened and slimy (flatworms). Many kinds of nematodes are found in the soil of any landscape.

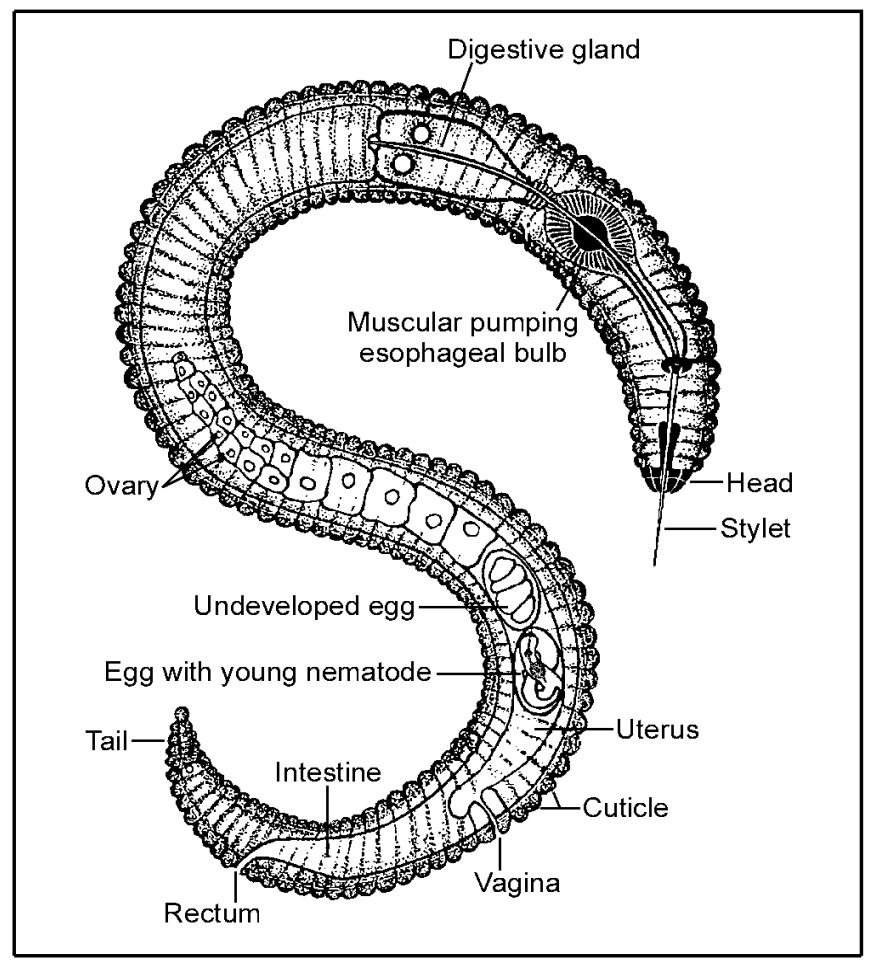

Figure 1. Diagram of a typical plant-parasitic nematode.

Most are beneficial, feeding on bacteria, fungi, or other microscopic organisms and some may be used as biological control organisms to help manage important insect pests (http://edis.ifas.ufl.edu/IN468).

1. This document is ENY-051, one of a series of the Entomology and Nematology Department, Florida Cooperative Extension Service, Institute of Food and Agricultural Sciences, University of Florida, Gainesville, FL. Publication date: April 2003. For more publications related to horticulture/agriculture, please visit the EDIS Website at http://edis.ifas.ufl.edu/.

2. William T. Crow, assistant professor, Entomology \& Nematology Department, Cooperative Extension Service, Institute of Food and Agricultural Sciences, University of Florida, Gainesville, 32611.

The use of trade names in this publication is solely for the purpose of providing specific information. UF/IFAS does not guarantee or warranty the products named, and references to them in this publication does not signify our approval to the exclusion of other products of suitable composition. All chemicals should be used in accordance with directions on the manufacturer's label. Use pesticides safely. Read and follow directions on the manufacturer's label.

The Institute of Food and Agricultural Sciences is an equal opportunity/affirmative action employer authorized to provide research, educational information and other services only to individuals and institutions that function without regard to race, color, sex, age, handicap, or national origin. For information on obtaining other extension publications, contact your county Cooperative Extension Service office. Florida Cooperative Extension Service/Institute of Food and Agricultural Sciences/University of Florida/Christine Taylor Waddill, Dean. 
Unfortunately, there are also a group of nematodes that feed on plants, called plant-parasitic nematodes (Figure 1).

Plant-parasitic nematodes are very small and most can be seen only by using a microscope (Figure 2). All plant-parasitic nematodes have a stylet or mouth-spear that is similar in structure and function to a hypodermic needle (Figure 3). The nematode uses its stylet to puncture plant cells and then inject digestive juices and ingest plant fluids through it. Most of the plant-parasitic nematodes that are important on ornamental plants in Florida feed on roots. Some plant-parasitic nematodes remain in the soil and feed by inserting only their stylet into the root; these are called ectoparasitic nematodes (Figure 4). Nematodes that enter the plant with part or all of their body are called endoparasites. Some endoparasites continually burrow around inside the root; these are called migratory endoparasites (Figure 5). Other endoparasites, called sedentary endoparasites, establish permanent feeding sites inside the root. Once a feeding site is established the nematode no longer moves. The sedentary endoparasite's body changes shape and is usually swollen (Figure 6).

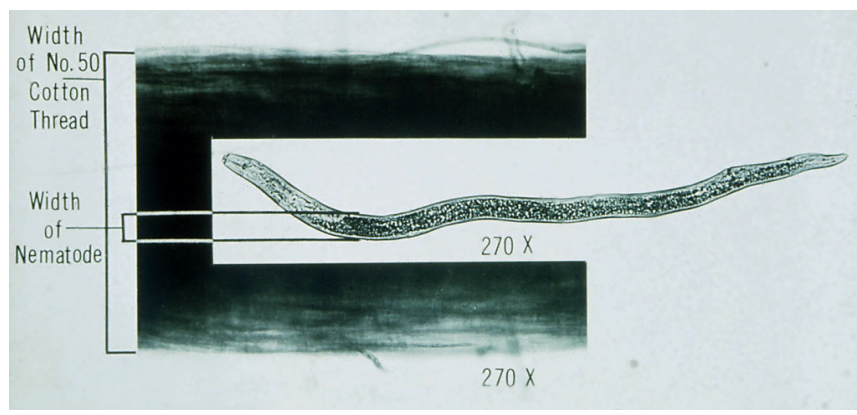

Figure 2. Size comparison of a typical plant-parasitic nematode to a cotton thread.

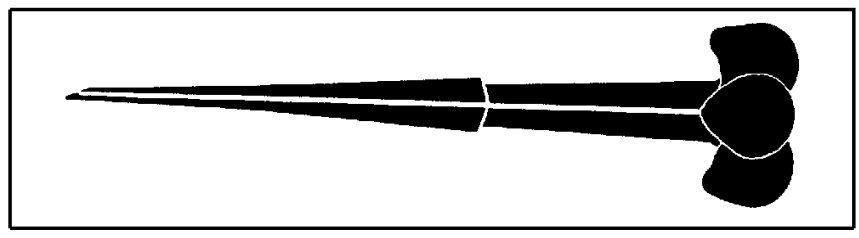

Figure 3. A typical plant-parasitic nematode stylet resembles a hypodermic needle.

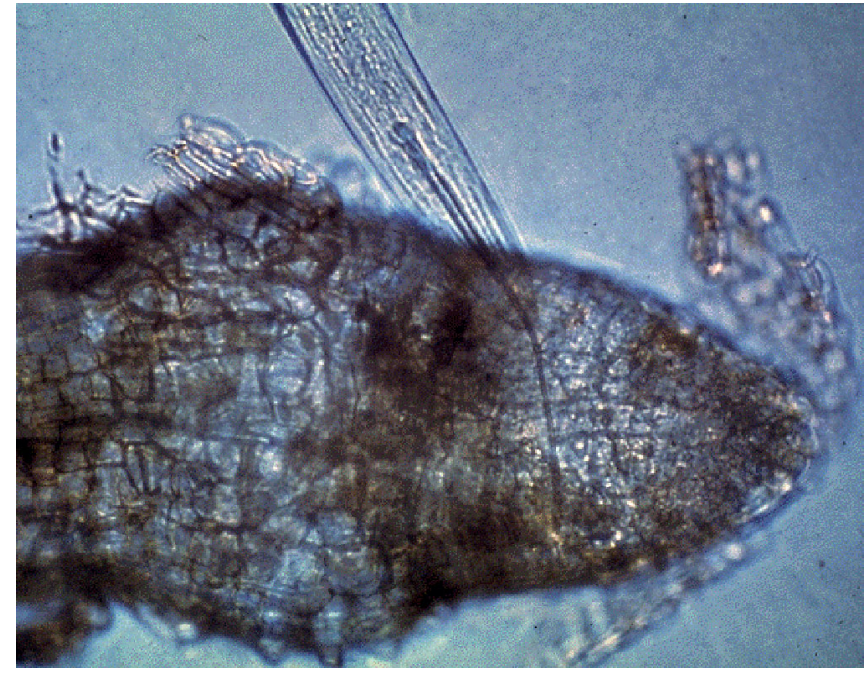

Figure 4. An ectoparasitic nematode feeding by inserting its stylet into a root tip.

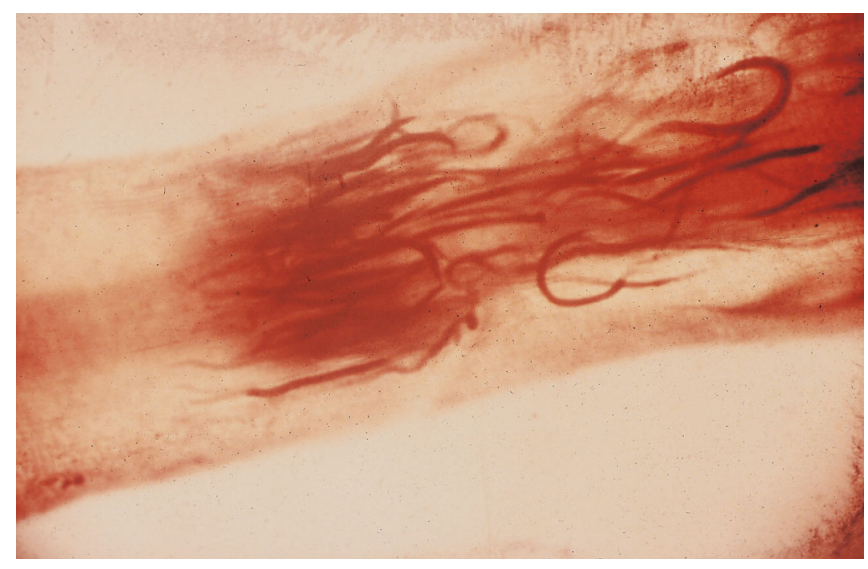

Figure 5. Endoparasitic nematodes burrowing within a root.

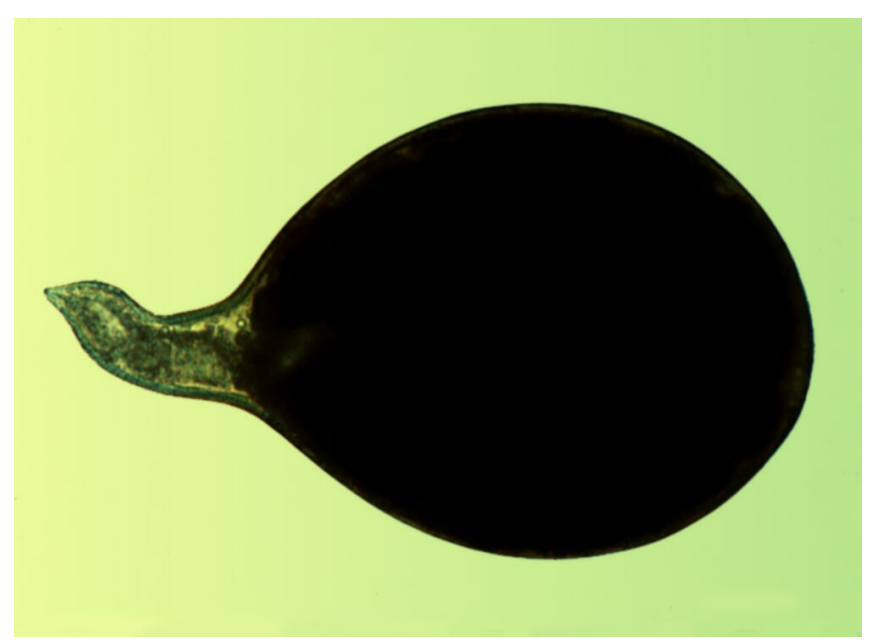

Figure 6. An adult female cyst nematode. This is a sedentary endoparasite.

How Do Nematodes Damage Plants? 
As plant-parasitic nematodes feed, they damage the root system and reduce the ability of the plant to obtain water and nutrients from the soil. When nematode numbers get high, and/or when environmental stresses occur, aboveground symptoms may become evident. Aboveground nematode symptoms often resemble nutrient deficiencies or drought stress. Symptoms include yellowing (Figure 7), wilting, thinning (Figure 8), stunting (Figure 9), or dying. Nematode damage usually occurs in localized areas that may enlarge slowly over time. In a hedge, a few affected plants may be surrounded by healthy ones (Figure 10). Be aware that similar conditions may be caused by other factors such as localized soil conditions, fungal diseases, or insects.

On trees and shrubs, root nematode damage usually becomes evident over a period of time. The plant canopy will get progressively thinner as leaves are shed. If a plant dies rapidly with the leaves still attached, nematodes usually are not the major problem.

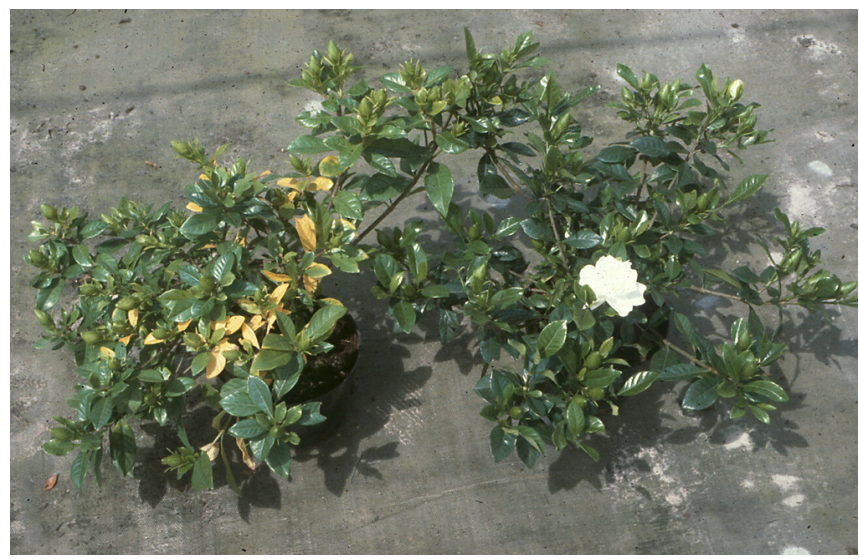

Figure 7. Nematode damage to roots can cause symptoms of nutrient deficiency. The gardenia on the left is being affected by root-knot nematodes.

\section{Root-knot Nematodes}

Root-knot nematodes are the most well known of the plant-parasitic nematodes. These are sedentary endoparasites. Four species are common in Florida on perennial landscape plants, Meloidogyne incognita, M. arenaria, $M$. javanica, and M. mayaguensis. These nematodes inject hormones into the roots that cause knots or galls to form (Figure 11). These galls are the only nematode symptoms that are easily recognized. Root-knot nematodes cause extensive damage and changes in the root system. These changes allow

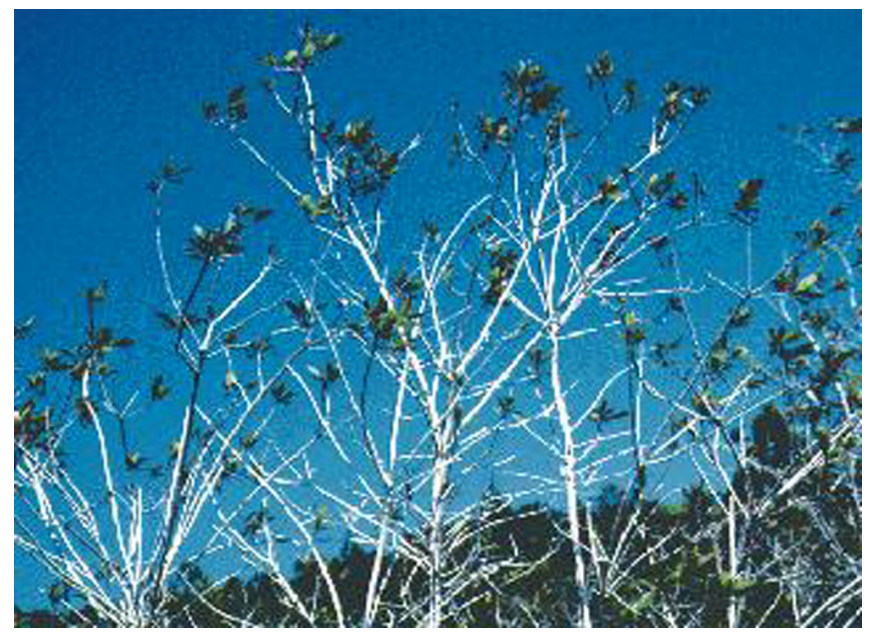

Figure 8. The roots of this wax myrtle are damaged by root-knot nematodes. Notice the thin canopy compared to the healthy plants behind it.

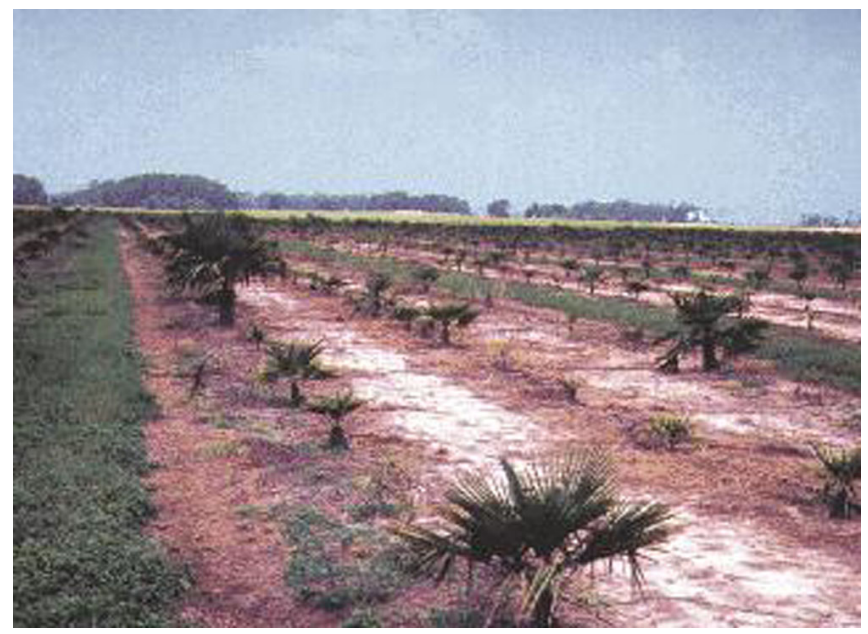

Figure 9. Many of the palms in this field are very stunted because of nematode infection.

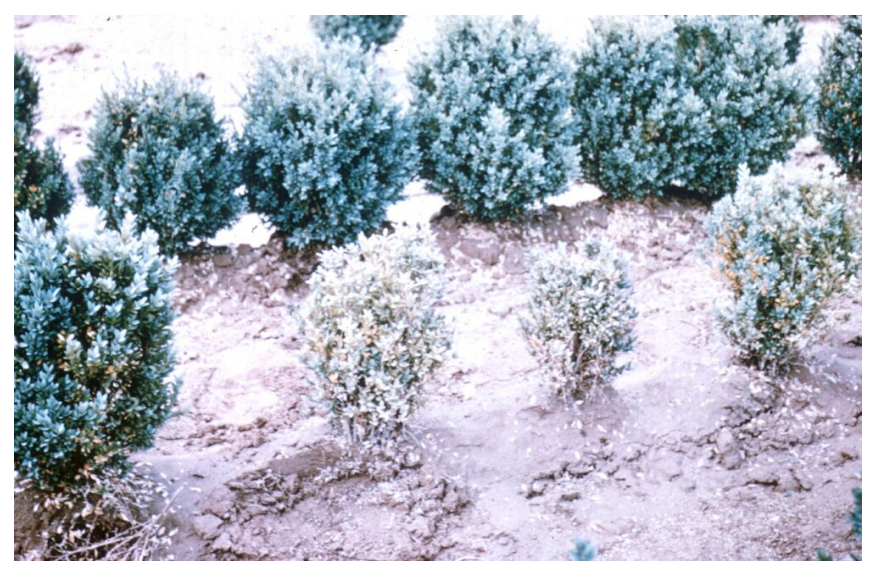

Figure 10. Boxwoods dying from root-knot nematode infection. Notice the affected plants are surrounded by healthy ones.

fungi and bacteria to get into the plant. Some of these organisms cause rotting of the root systems, and 
others cause vascular wilts. Sometimes the damage caused by the nematodes and the other organisms together is worse than that caused by either organism separately.

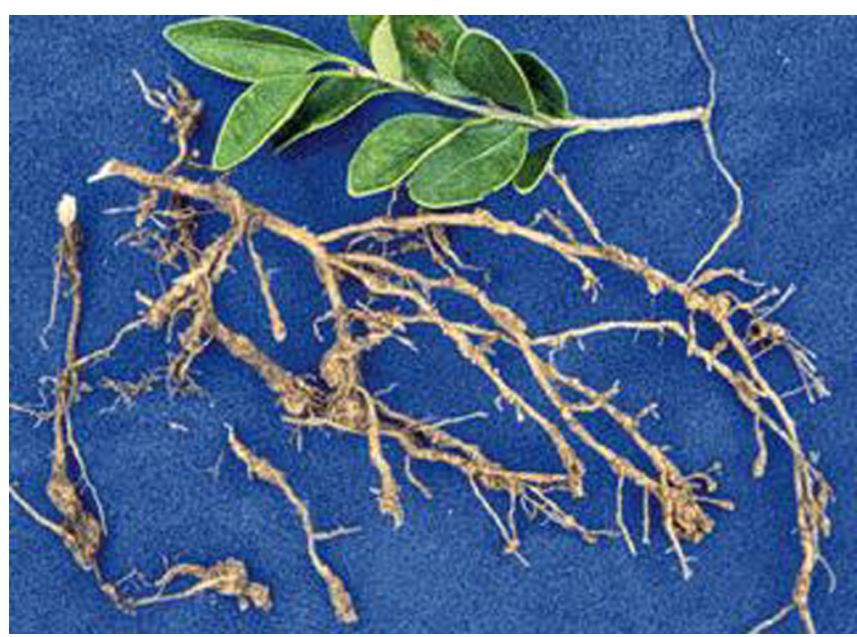

Figure 11. Knots or galls on roots, caused by root-knot nematodes.

Root-knot nematodes are one of the most destructive plant-parasites. High infestations can kill many types of perennial landscape plants. Other plants, like liriope and daylilies, are hosts to root-knot nematodes, but the nematodes seldom damage them. Still others are not fed on by root-knot nematodes at all. Table 1 has a list of woody landscape plants that are commonly damaged by root-knot nematodes in Florida. This is not an exhaustive list; as the majority of plants may be affected by root-knot occasionally.

\section{Other Sedentary Endoparasites}

Several genera of nematodes are sedentary endoparasites that occasionally damage ornamental plants in Florida. These nematodes do not cause galls like root-knot nematodes. Root symptoms are typically an unthrifty root system (Figure 12).

Reniform nematodes are limited to soils with high silt content. In Florida they are found most often in the Miami-Dade County area and parts of the panhandle. Reniform nematodes are damaging to many ornamental plants and tropical fruits in the limited areas where they occur.

In Florida, the citrus nematode is only a problem on citrus. This nematode normally does not kill citrus trees but causes them to be unthrifty and have

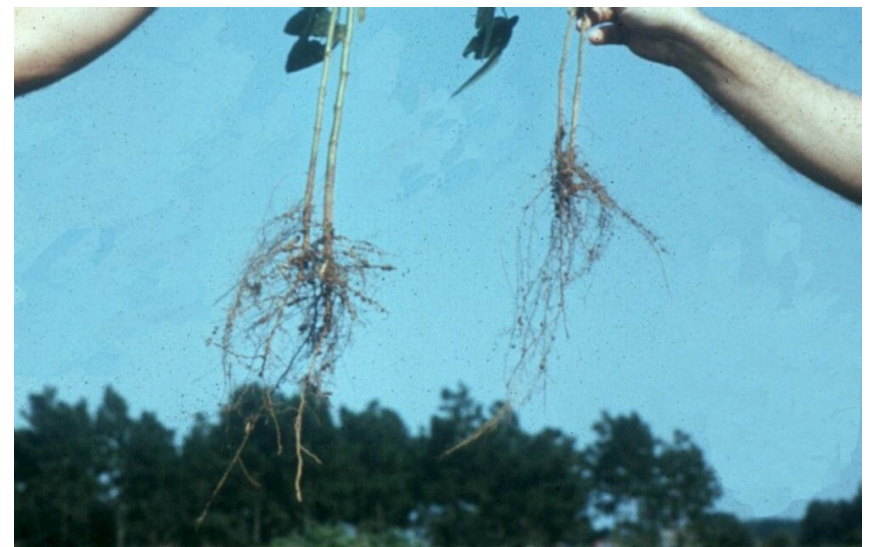

Figure 12. (Left) Healthy root system. (Right) Unhealthy root system, damaged by reniform nematodes.

reduced fruit production. This condition is known as slow decline of citrus (see http://edis.ifas.ufl.edu/CH101).

\section{Migratory Endoparasites}

Lesion nematodes are migratory endoparasites common in Florida soils. These nematodes usually cause dark sunken areas called lesions on roots (Figure 13). Lesion nematodes are particularly damaging to bulbs, and citrus, but some species can damage other perennial plants as well. The coffee lesion nematode causes "citrus slump", a devastating disease of citrus (Figure 14). Feeding by lesion nematodes can make plants susceptible to other pathogens. Fungi enter the wounds created by the nematodes and can cause rotting of roots, bulbs, and rhizomes.

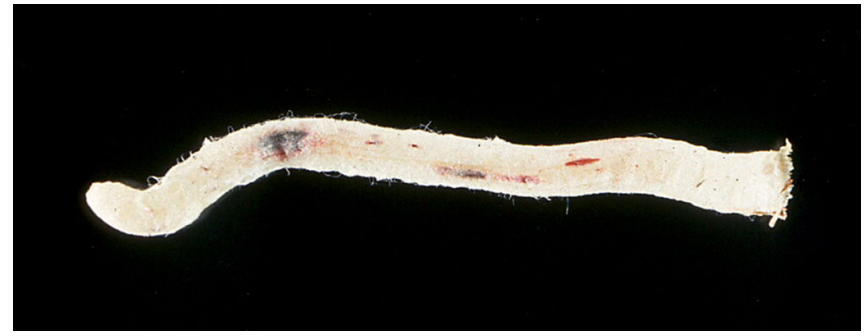

Figure 13. Some nematodes cause root-lesions.

Burrowing nematodes are very damaging but not widespread in Florida. Nursery stock are regularly inspected for this nematode which is a regulated pest in Florida. "Spreading decline" is the disease of citrus caused by burrowing nematodes. Burrowing nematodes cause lesions and rotting of roots (Figure 15). In Florida, these nematodes are 


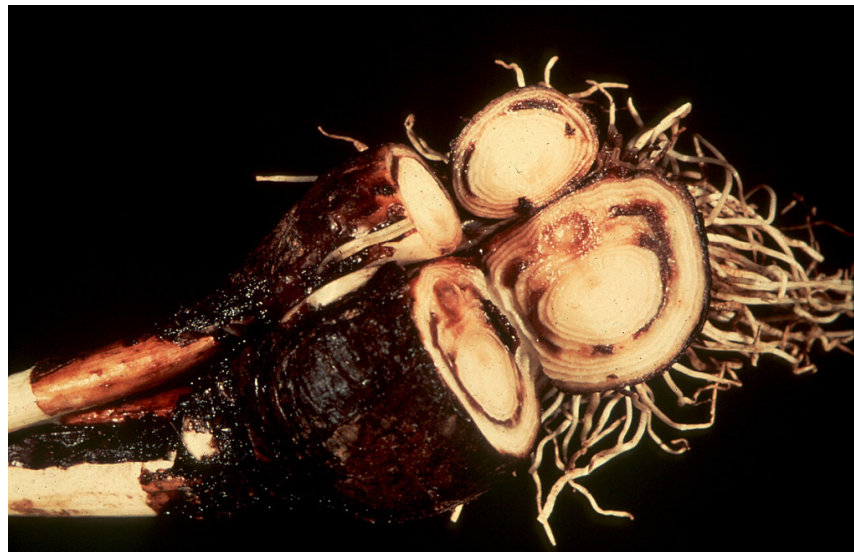

Figure 14. Rotting of Easter lily bulb caused by lesion nematodes.

damaging on citrus, banana and its relatives, palms, and other ornamental plants.

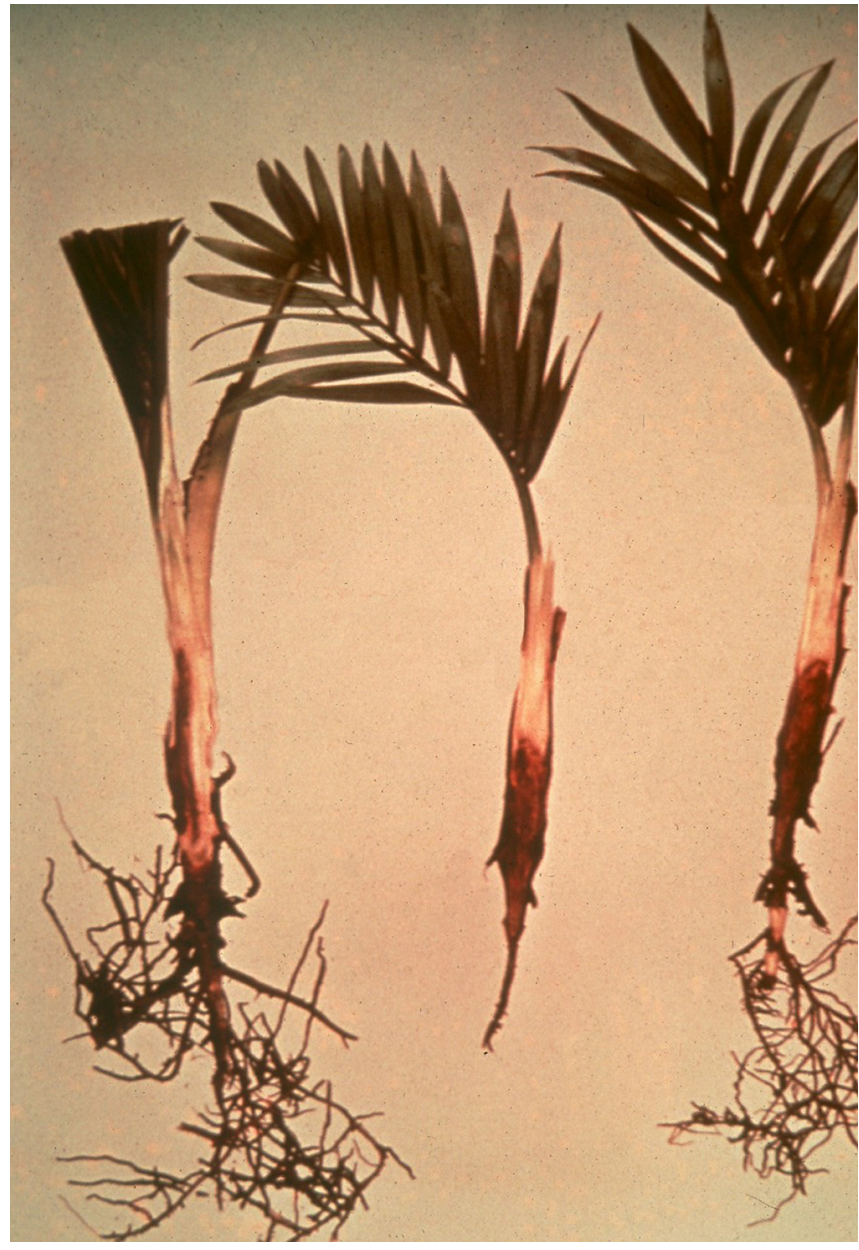

Figure 15. Rotting of palm roots caused by burrowing nematodes.

\section{Ectoparasites}

Several ectoparasitic nematodes are capable of causing damage to many landscape plants in Florida. The most destructive of these are the sting, awl, and stubby-root nematodes. Feeding by these nematodes usually causes a root system to be stunted or stubby looking (Figure 16). Sting nematodes are found in sandy soil and are common throughout much of Florida. Awl nematodes usually are found in wet habitats such as near ditches, ponds, or poorly drained areas. Several stubby-root species are found in Florida, and one or more usually can be found in most Florida habitats. Lance nematodes are sometimes damaging on azaleas in Florida. Some species of spiral nematodes are known to damage boxwood. In extreme northern Florida, where peaches can be grown, ring nematodes cause a disease known as "peach tree short life." Other ectoparasitic nematodes that parasitize some landscape plants are stunt, sheath, sheathoid, dagger, and needle nematodes.

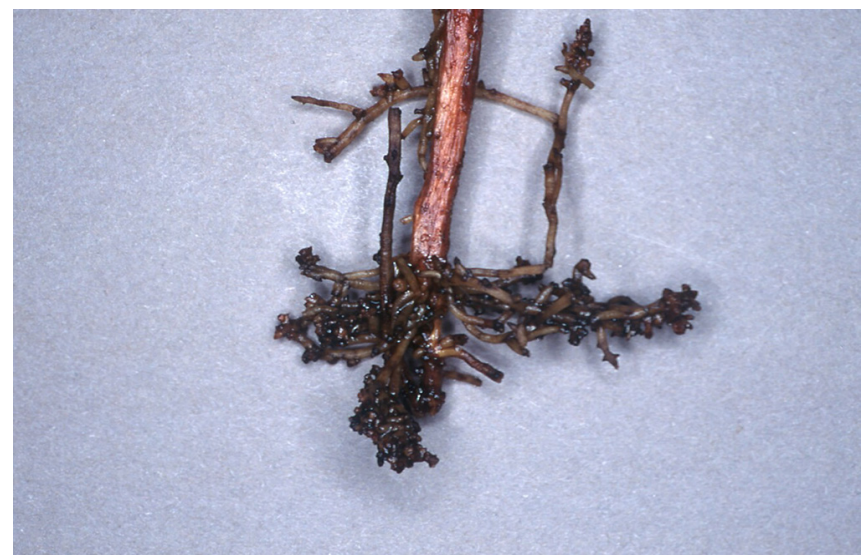

Figure 16. Some nematodes cause an abbreviated or "stubby" root system.

\section{Vascular Nematodes}

While most plant-parasitic nematodes feed on plant roots, there are a few that feed in the water-conducting system of some trees. These nematodes are spread by certain beetles.

Pine wilt nematode (Bursaphelenchus xylophilus) infects pine trees. It plugs up the vascular system and reduces the flow of water up to the foliage. The pine needles droop, turn brown, and die. Pine wilt nematode is native to the United States, and our native pines are usually tolerant of them. 
However, in times of drought, pine wilt nematodes will cause additional stress to the trees. Pine species that originate in Asia and Europe, where pine wilt nematodes are not native, are very susceptible to pine wilt nematodes. Susceptible pines include: Scotch pine, Austrian pine, Japanese black pine, Mugo pine, Japanese red pine.

Red ring nematode (Bursaphelenchus cocophilus) is very damaging to coconut and oil palms. This nematode causes major problems for coconut production throughout the Carribean region, but is not yet present in Florida. If this nematode does get into Florida, it could cause serious damage to our coconut, and certain other palms.

\section{How Do I Know if Nematodes are a Problem?}

With any plant problem, having an accurate diagnosis is important to address the problem and to avoid wasting effort and unnecessary pesticide applications. Generally, nematode symptoms are identical to other disorders so visual inspection is not enough. The only reliable way to determine if plant-parasitic nematodes are involved in a plant problem is by having a nematode assay conducted by a professional nematode diagnostic lab. The University of Florida Nematode Assay Lab (http://edis.ifas.ufl.edu/SR011) will evaluate nematode samples for a cost of $\$ 12.00$ each. Nematode sample kits (Figure 17) containing everything needed to collect and submit a sample, along with instructions, are available at your local county Cooperative Extension office.

Nematode analysis is a separate procedure and requires different sampling guidelines than those required for soil analysis or plant disease samples. Do not send samples in soil test bags! The addresses are different and, more importantly, the soil testing bags are designed to dry soil out. Drying invalidates the results of a nematode assay. The accuracy of the diagnosis depends on the quality of the sample that you submit. If you are taking a sample for submission to another lab, or if you are submitting a sample to the University of Florida lab without using our sample kits, following the guidelines below will help insure an accurate diagnosis.

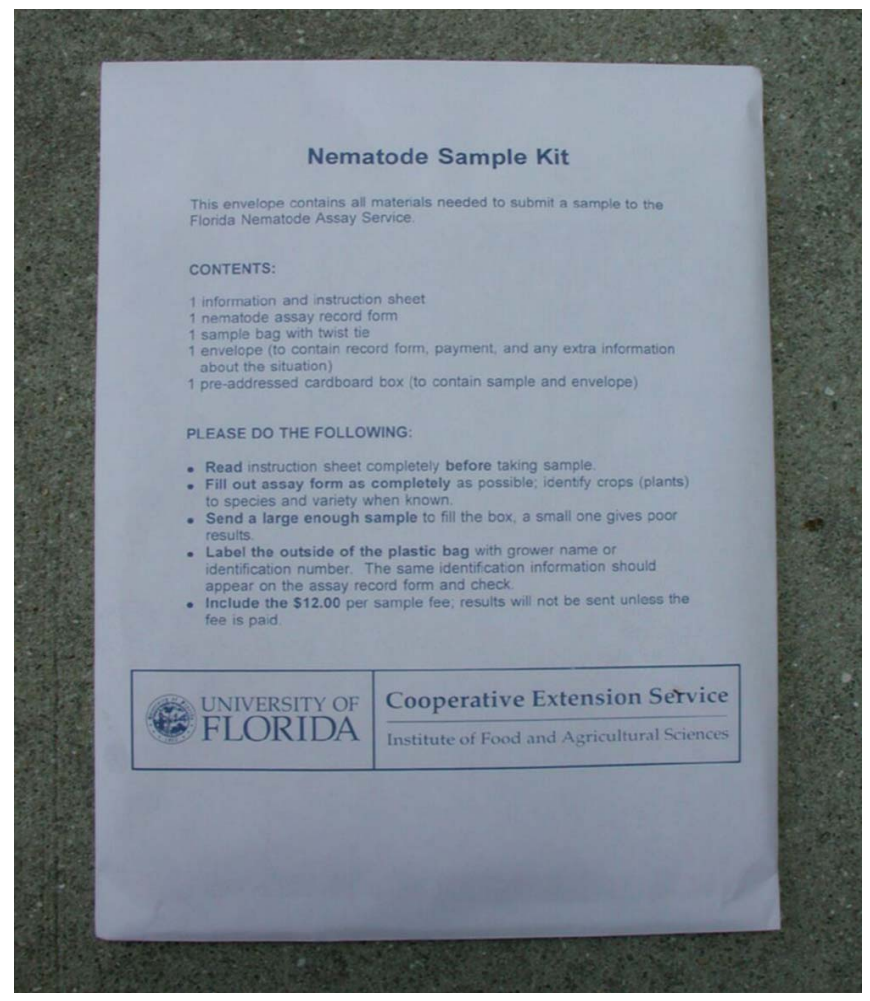

Figure 17. The University of Florida Nematode Assay Kit.

\section{Sampling}

Before planting: Collect soil from 8 to 12 locations in a planting area. Samples should be taken 8 to 10 inches deep. About a handful of soil from each location is adequate. Combine all the soil into a single plastic bag. The total volume of soil from the samples should be between 1 pint and a half gallon. Samples may be taken with a shovel, trowel or other device. If using a shovel you can put part of the soil from 8 to 12 shovel fulls into a bucket. Thoroughly mix the soil in the bucket then take out a pint for analysis.

After planting: Often a nematode assay is needed to determine if nematodes are causing a plant to get sick. For this type of sample both soil and roots are required! Dig soil and roots from around the drip line of the plant. Sample depth depends on the size of the plant. For most woody ornamentals sample 8 to 10 inches deep. Tree samples should be 12 inches deep. Do not include the top 1 inch of soil. If multiple plants are affected collect some soil and roots from several plants. Place the soil and roots together in the same plastic bag. A minimum of 1 pint of soil and 1 to 2 cups of roots are required. 


\section{Handling}

1) If submitting more than one sample make sure that the outside of each bag is labeled with a permanent marker. You also can write on masking tape stuck to the bag. Do not put paper labels inside of bags, they will decompose and be illegible. If submitting several samples together wrap each in newspaper so that the labeling doesn't wear off.

2) Seal the plastic bags to keep the sample moist. Dried out samples are no good for nematode diagnosis. Self-sealing bags often come open in the mail. If using a self-sealing bag tape the seal shut.

3) Keep samples out of direct sunlight or heat. Heat and ultraviolet light kill nematodes. Even a few minutes on the dashboard or in the back of a pickup can invalidate assay results. If you are storing the sample for more than a day it is best to keep it refrigerated, but not frozen.

4) Handle the sample gently and pack it well. Nematodes are between soil particles. So, the more the soil gets banged around the more the nematodes may get destroyed.

5) Fill out the information on the nematode assay form (http://edis.ifas.ufl.edu/pdffiles/SR/SR02300.pdf). In order to make a diagnosis we need to know as much as possible about the plant or plants in question. Make sure that the identification on the form matches the identification on the sample bag.

\section{Submitting the Sample}

1) There is a $\$ 12$ fee for each nematode sample. Place a check or money order payable to the "Florida Nematode Assay Service" into an envelope. Do not send cash.

2) Put the sample, assay form, and payment envelope into box. Seal the box with gummed tape.

3) Mail, ship, or deliver the samples to the Nematode Assay Lab as soon as possible. The mailing address is: Nematode Assay Lab, Building 78 Mowry Rd., Gainesville, FL 32611.

\section{What Can I Do About Nematodes?}

\section{Chemicals}

Unfortunately, there are no effective nematicides labeled for use on perennial landscape plants at this time.

\section{Resistance and Tolerance}

Plants on which particular nematode cannot reproduce are termed resistant to that nematode. Plants that can be fed on by the nematode but are not damaged are termed tolerant. While a great deal of work has gone into identifying nematode resistant agronomic and vegetable crops, little work has been done with landscape plants. This is an area of research we are currently exploring at the University of Florida. For now, the plants identified as susceptible in Table 1 should be avoided in areas where root-knot nematodes are known to occur.

\section{Organic Amendments}

Organic amendments can be added to soil as compost, manure, mulch, or other materials. Organic matter can help prevent nematode damage in several ways. The organic matter increases the ability of the soil to hold water and nutrients, and improve soil structure. This makes a better environment for most plants and can help the plants survive in spite of the nematodes. Organic amendments also can increase natural enemies of nematodes that suppress the nematode populations. Some organic amendments can release chemicals or gases that are toxic to the nematodes.

There are several organic nematode management products for sale. Researchers with the University of Florida have worked with a number of these, but probably not all of them. In the majority of cases, these products work no better than adding any other, less expensive, organic material.

For more detailed information on these topics see "Soil organic matter, green manures, and cover crops for nematode management" online at http://edis.ifas.ufl.edu/VH037 or at your county Cooperative Extension Service office. 


\section{Sanitation}

Roots left in the soil can continue to live and support nematode reproduction. Endoparasitic nematode eggs are attached to roots and will continue to hatch after the plant appears dead. Therefore, as soon as it is clear that a plant is dying it is best to pull it up. Make sure to dig up as many roots as possible and destroy them.

Always be aware that when soil is moved pathogens can be moved with it. After digging up sick plants make sure that any shovels or other equipment are thoroughly cleaned after use. It is best to rinse the equipment with a solution of 1 part bleach in 9 parts water to disinfest the surface. This should remove any plant-parasitic nematodes or other pathogens in adhering soil.

\section{Summary}

Following the recommendations listed in this document can help avoid or reduce problems with plant-parasitic nematodes in the landscape. However, there are no guarantees of success. County and state faculty with the University of Florida are continually exploring new nematode management options. This document will be updated yearly to make the most recent data available to you. If you are reading an older version of this document you are encouraged to look at the current version on-line at http://edis.ifas.ufl.edu/ or at your county Cooperative Extension Service office.

Table 1. Woody Landscape plants commonly damaged by root-knot nematodes in Florida as diagnosed by the University of Florida Nematode Assay Lab.

\begin{tabular}{||l|l||}
\hline \multicolumn{1}{|c||}{ Common Name } & \multicolumn{1}{c||}{ Scientific Name } \\
\hline Boxwood & Buxus spp. \\
\hline Butterfly bush & Buddleia spp. \\
\hline Hibiscus & Hibiscus rosa-sinensis \\
\hline Gardenia & Gardenia spp. \\
\hline Bottlebrush & Callistemon spp. \\
\hline Pittosporum & Pittosporum tobira \\
\hline Japanese Holly & Ilex crenata \\
\hline Rose & Rosa spp. \\
\hline Lantana & Lantana spp. \\
\hline Ixora & Ixora coccinea \\
\hline \hline
\end{tabular}


Table 2. Susceptibility of some popular woody ornamentals to four common nematodes at the NCSU Central Crops

Research Station, Clayton, NC.* Key to ratings: HS - Plants highly susceptible (severe stunting, branch die-back and death), $S$ - Plants susceptible (some stunting but plants will grow satisfactorily), T - Plants will grow satisfactorily, O - Untested.

\begin{tabular}{|c|c|c|c|c|}
\hline \multirow[b]{2}{*}{ Host Plant } & \multicolumn{4}{|c|}{ Nematode Reaction } \\
\hline & Root-knot & Stunt & Lesion & Ring \\
\hline Azalea & $\mathrm{T}$ & $\mathrm{S}$ & 0 & $T$ \\
\hline Aucuba japonica & HS & $\mathrm{S}$ & 0 & $\mathrm{~S}$ \\
\hline Buxus microphylla (Japanese Boxwood) & $\mathrm{HS}$ & $\mathrm{O}$ & $\mathrm{O}$ & $\mathrm{O}$ \\
\hline Buxus sempervirens (American Boxwood) & $\mathrm{O}$ & $\mathrm{T}$ & $\mathrm{HS}$ & $\mathrm{O}$ \\
\hline Camellia japonica & $T$ & $\mathrm{~T}$ & 0 & $\mathrm{O}$ \\
\hline Camellia sasanqua & $\mathrm{T}$ & $\mathrm{T}$ & $\mathrm{O}$ & $\mathrm{O}$ \\
\hline Gardenia jasminoides & $\mathrm{S}$ & $\mathrm{T}$ & $T$ & $\mathrm{~T}$ \\
\hline Gardenia radicans & $\mathrm{HS}$ & $\mathrm{T}$ & $\mathrm{O}$ & $\mathrm{T}$ \\
\hline \multicolumn{5}{|l|}{ Ilex cornuta (Chinese Holly) } \\
\hline cv. Burfordi & $\mathrm{T}$ & $\mathrm{T}$ & 0 & $\mathrm{~T}$ \\
\hline cv. Rotunda & S & $\mathrm{S}$ & $\mathrm{O}$ & $\mathrm{S}$ \\
\hline \multicolumn{5}{|l|}{ Ilex crenata (Japanese Holly) } \\
\hline cv. Compacta & $\mathrm{HS}$ & $\mathrm{T}$ & $\mathrm{O}$ & $\mathrm{S}$ \\
\hline cv. Convexa & $\mathrm{HS}$ & $\mathrm{T}$ & $\mathrm{O}$ & $\mathrm{S}$ \\
\hline cv. Helleri & $\mathrm{HS}$ & $\mathrm{S}$ & $\mathrm{O}$ & $\mathrm{S}$ \\
\hline cv. Rotundifolia & $\mathrm{HS}$ & $\mathrm{S}$ & $\mathrm{O}$ & $\mathrm{S}$ \\
\hline Ilex vomitoria nana & $\mathrm{T}$ & $\mathrm{T}$ & 0 & $\mathrm{~T}$ \\
\hline \multicolumn{5}{|l|}{ Juniper sp. } \\
\hline - Blue rug & $\mathrm{T}$ & $\mathrm{T}$ & $\mathrm{HS}$ & $\mathrm{T}$ \\
\hline - Shore juniper & $\mathrm{T}$ & $\mathrm{T}$ & $\mathrm{O}$ & $\mathrm{T}$ \\
\hline - Spiney Greek & $\mathrm{T}$ & $\mathrm{T}$ & $\mathrm{S}$ & $\mathrm{T}$ \\
\hline Ligustrum (Privet) & $\mathrm{T}$ & $\mathrm{T}$ & $\mathrm{O}$ & $\mathrm{T}$ \\
\hline Nandina domestica & $\mathrm{T}$ & $\mathrm{T}$ & $\mathrm{T}$ & $\mathrm{T}$ \\
\hline Photinia fraseri (red tip) & $\mathrm{T}$ & $\mathrm{T}$ & $\mathrm{O}$ & $\mathrm{T}$ \\
\hline Rose & $\mathrm{s}$ & S & $\mathrm{S}$ & $\mathrm{T}$ \\
\hline
\end{tabular}

